\title{
Simulasi Filter Aktif pada 6 Pulse STATCOM Untuk Mereduksi Total Harmonic Distortion (THD) Di Sistem Transmisi Bali
}

\author{
Made Dika Nugraha ${ }^{1}$, Ida Bagus Gede Manuaba ${ }^{2}$, Rukmi Sari Hartati ${ }^{3}$ \\ [Submission: 19-01-2019, Accepted: 24-06-2019]
}

\begin{abstract}
The emergence of harmonics is caused by the operation of nonlinear electrical loads. Harmonics can cause the waveform to be non sinusoidal, especially the input current. Harmonic content that exceeds the limit can cause poor quality. The level of harmonic distortion or called Total Harmonic Distortion (THD) in the transmission network has the potential to cause losses and drop voltages which affect the efficiency of the transmission network system. Harmonic attenuation is the right choice to reduce current harmonics (THDi). In this study an active filter has been designed to be able to reduce the harmonic current contained in the system due to the use of 6 pulse converter load on Statcom. The method used is by injecting dc ripple using the 6 output converter pulse connected to a controlled rectifier, where the dc ripple size is regulated by setting the ignition of the thyristor which is arranged in a bridge. Current harmonic conditions in the Bali transmission network before and after the installation of active filter installations on the 6 pulse Statcom, namely the $3^{\text {th }}$ order experienced harmonic wave distortion from 0.0014 to $0.000230,5^{\text {th }}$ order from 9.4736 to 0.0249 , order $7^{\text {th }}$ from 3.4970 to $0.0117,9^{\text {th }}$ order from 0.0120 to $0.000873,11^{\text {th }}$ order from 0.9559 to 0.00486 , order $13^{\text {th }}$ from 0.8188 to 0.00339 , order $15^{\text {th }}$ from 0.3450 to 0.000979 .
\end{abstract}

Intisari-Timbulnya harmonisa disebabkan karena pengoperasian beban listrik nonlinier. Harmonisa dapat menyebabkan bentuk gelombang menjadi tidak sinusoidal terutama arus input. Kandungan harmonisa yang melebihi batas dapat menyebabkan kualitas daya yang tidak baik. Tingkat distorsi harmonisa atau disebut dengan Total Harmonic Distortion (THD) pada jaringan transmisi berpotensi menimbulkan losses maupun drop voltage sehingga berpengaruh terhadap efisiensi sistem jaringan transmisi. Peredaman harmonisa merupakan pilihan yang tepat untuk mengurangi harmonisa arus $\left(\mathrm{THD}_{\mathrm{i}}\right)$. Pada penelitian ini telah dirancang sebuah filter aktif agar mampu meredam arus harmonisa yang terkandung pada sistem akibat penggunaan beban konverter 6 pulsa pada Statcom. Metode yang digunakan yaitu dengan menginjeksikan dc ripple memanfatkan keluaran konverter 6 pulsa dihubungkan ke rectifier terkontrol, dimana besarnya $d c$ ripple ini diatur dengan pengaturan penyalaan thyristor yang disusun secara jembatan. Kondisi harmonisa arus pada jaringan

${ }^{1}$ Mahasiswa, Jurusan Magister Teknik Elektro Fakultas Teknik Universitas Udayana, Jln. Jalan Kampus Bukit Jimbaran 80361 INDONESIA (telp: 0361-703315; fax: 0361-4321;e-mail: nugrahamadedika@gmail.com)

2, 3 Dosen,Jurusan Teknik Elektro dan Komputer Fakultas Teknik Universitas Udayana, Jln. Jalan Kampus Bukit Jimbaran 80361 INDONESIA (telp: 0361-703315; fax: 0361-4321)

Made Dika Nugraha: Mereduksi Filter Aktif Pada... . transmisi Bali sebelum dan sesudah simulasi pemasangan filter aktif pada 6 pulse STATCOM yaitu orde $3^{\text {th }}$ mengalami distorsi gelombang harmonisa dari 0,0014 menjadi 0,000230 , orde $5^{\text {th }}$ dari 9,4736 menjadi 0,0249 , orde $7^{\text {th }}$ dari 3,4970 menjadi 0,0117 , orde $9^{\text {th }}$ dari 0,0120 menjadi 0,000873 , orde $11^{\text {th }}$ dari 0,9559 menjadi 0,00486 , orde $13^{\text {th }}$ dari 0,8188 menjadi 0,00339 , orde 15 th dari 0,3450 menjadi 0,000979 .

Kata Kunci-Active Filter, Total Harmonic Distotion,), Gate-Turn off Thyristor, STATCOM, Voltage Source Converter.

\section{PENDAHULUAN}

Dengan semakin berkembangnya pemakaian elektronika daya dalam sistem tenaga listrik, maka semakin banyak pula beban nonlinier yang terpasang. Meningkatnya beban berbasis elektronika daya ternyata menimbulkan permasalahan yang cukup serius pada kualitas energi listrik, yaitu terjadinya distorsi bentuk gelombang tegangan maupun arus yang disebabkan oleh adanya harmonisa. Untuk menanggulangi ganguan harmonisa perlu adanya pemasangan filter untuk mereduksi harmonisa dari suatu sistem tenaga. Filter aktif ada dua yaitu filter aktif series berfungsi untuk mereduksi harmonisa tegangan dan filter aktif shunt berfungsi untuk mereduksi arus harmonisa yang memiliki orde ganjil seperti $3,5,7,9,11,13,15$.

Penemuan FleksibelSistem AC Transmission (FACTS) perangkat telah mengatasiketerbatasan metode tradisional daya reaktifkompensasi [1]. Sistem Transmisi 150 $\mathrm{kV}$ di Bali pun masih besifat tradisional dengan menggunakan kapasitor bank sebagai kompensasi daya. Perangkat FACTS memiliki kemampuan untukmengakomodasi perubahan dalam kondisi operasi transmisisistem dengan tetap mempertahankan kondisi steady state dan margin [2] STATCOM adalah sebuahshunt terhubung perangkat FACTS, yang mampu menyediakanbaik kompensasi kapasitif dan induktif [3]. terdiri dari beberapa bagian yaitu Voltage Source Converter (VSC),STATCOM digunakan untukmengendalikan tegangan salurantransmisi, meningkatkan dayamengalir, meningkatkan stabilitas sistem daya dan redamanosilasi daya [4].

Sistem $150 \mathrm{kV}$ Bali merupakan sistem tenaga listrik yang memiliki pola pembebanan yang tinggi, terdiri dari 1 busslack, 2 bus generator dan 12 bus beban. Dengan beban puncak listrik di Bali sebesar 758,7 MW (rekor beban tertinggi 758,7 MW (21/10/2014)). Melihat kondisi ini, sistem $150 \mathrm{kV}$ Bali sedang menghadapi krisis energi listrik. Apabila salah satu pembangkit mengalami black out, maka dapat dipastikan pulau Bali akan mengalami pemadaman bergilir. Ini pernah diteliti sebelumnya oleh Made Dika

$$
\text { p-ISSN:1693 - 2951; e-ISSN: 2503-2372 }
$$

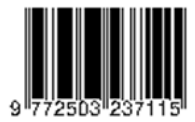


dengan menggunakanStatcom untuk memperbaiki profil tegangan dan stabilitas daya pada sistem $150 \mathrm{kV}$ Bali akibat adaya jatuh tegangan pada sisi transmisi, dalam penelitian tersebut didapat nilai arus harmonisa akibat pemasangan statcom di sistem transmisi yang belum terbahas, hal tersebut akan mendorong peneliti untuk membahas tentang simulasi reduksi total harmonisa pada 6 pulse Statcom dengan menggunakan filter aktif shunt pada sistem $150 \mathrm{kV}$ Bali.

\section{HARmonisa, Filter AKTiF Shunt dAN StATCOM PAdA JARINGAN TRANSMISI}

\section{A. Harmonisa}

Harmonisa adalah distorsi perodik dari gelombang sinus tegangan, arus atau daya dengan bentuk gelombang frekuensinya merupakan kelipatan diluar bilangan satu terhadap frekuensi fundamental (frekuensi $50 \mathrm{~Hz}$ atau $60 \mathrm{~Hz}$ ). Nilai frekuensi dari gelombang harmonisa terbentuk merupakan hasil kali antara frekuensi fundamental dengan bilangan harmonisanya (f, $2 \mathrm{f}, 3 \mathrm{f}$, dst).

\section{B. Sumber-Sumber Harmonisa}

Pada umumnya harmonisa di timbulkan oleh bebanbeban tak linier tersebut dapat menyebabkan distorsi bentuk gelombang arus maupun tegangan.

Diantaranya beban-beban yang menyebabkan harmonisa yaitu Konveter, Transformator, Mesin - mesin berputar, Tanur busur listrik, Penyearah enam pulsa, Kompensator VAR Statis Beberapa sumber harmonisa beserta ordenya seperti tabel dibawah ini :

TABELI

SUMBER HARMONISA DAN ORDE HARMONISA

\begin{tabular}{|l|l|}
\hline Sumber Harmonisa & Orde Harmonisa \\
\hline 6 Pulse Drive/ Rectifier & $5,7,11,13,17,19$ \\
\hline 12 Pulse Drive/ Rectifier & $11,13,23,25$ \\
\hline Switch-Mode Power Supply & $3,5,7,9,11,13 .$. \\
\hline Fluorescent/LHE & $3,5,7,9,11,13 .$. \\
\hline Arching Device & $2,3,4,5,7 .$. \\
\hline Transformer Energizaton & $2,3,4$ \\
\hline
\end{tabular}

Untuk converter dengan 6 pulsa akan membangkitkan karakteristik harmonisa pada orde $5^{\text {th }}, 7^{\text {th }}, 11^{\text {th }}, 13^{\text {th }}, \ldots$ kelipatan dari frekuensi fundamental

\section{Standar Harmonisa}

Standar harmonisa yang digunakan adalah IEEE std. 5191992. $\mathrm{THD}_{\mathrm{i}}$ adalah persentase jumlah total arus yang terdistorsi oleh harmonisa terhadap frekuensi fundamentalnya. [8]
TABELII

STANDAR HARMONISA TEGANGAN (IEEE519-1922)

\begin{tabular}{|c|c|c|}
\hline Sistem Voltage & $\mathrm{IHD}_{\mathrm{v}}(\%)$ & $\mathrm{THD}_{\mathrm{v}}(\%)$ \\
\hline $\mathrm{V}_{\mathrm{rms}} \leq 69 \mathrm{kV}$ & 3.0 & 5.0 \\
\hline $69 \mathrm{kV} \leq \mathrm{V}_{\mathrm{rms}} \leq 161 \mathrm{kV}$ & 1.5 & 2.5 \\
\hline $\mathrm{V}_{\mathrm{rms}} \geq 161 \mathrm{kV}$ & 1.0 & 1.5 \\
\hline
\end{tabular}

\section{Total Harmonic Distortion}

Pendefisian nilai rms komponen harmonisa ke nilai rms komponen dasar biasanya dinyatakan dalam bentuk persen (\%). Indeks ini digunakan untuk mengukur deviasi bentuk gelombang periodik yang mengandung harmonisa dari gelombang sinus sempurna. Pada saat terjadi gelombang sinus sempurna. Nilai THD adalah nol. Indeks yang umum digunakan adalah :

$\mathrm{THD}_{\mathrm{v}}=\frac{\sqrt{v_{2}^{2}+v_{3}^{2}+v_{4}^{2}+\cdots v_{n}^{2}}}{v_{1}}$ (THD untuk tegangan)
$\mathrm{THD}_{\mathrm{i}}=\frac{\sqrt{I_{2}^{2}+I_{3}^{2}+I_{4}^{2}+\cdots I_{n}^{2}}}{I_{1}}$ (THD untuk arus)

Keterangan :

$\mathrm{V}_{\mathrm{n}} ; \mathrm{I}_{\mathrm{n}}=$ Orde Harmonisa

$\mathrm{V}_{1} ; \mathrm{I}_{1}=$ Orde Fundamental

\section{E. Filter Harmonisa}

Pemasangan filter harmonisa bertujuan untuk mereduksi amplitudo frekuensi tertentu dari sebuah tegangan dan arus.

\section{F. Filter Aktif Shunt}

Filter aktif ini berfungsi untuk mereduksi komponen harmonisa pada arus. Atau dapat disimpulkan filter Aktif shunt.Kontrol Filter Aktif berfungsi untuk pengolahan sinyal dalam menetukan real time referensi arus kopensasi spotan, yang secara kontinyu dilewatkan ke converter [14].

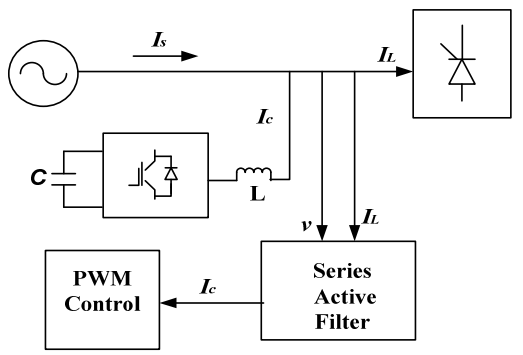

Gambar1: Shunt Active Filter[13].

\section{G. Static Compensator (Statcom)}

Static synchronous compensator (Statcom) merupakan salah satu shunt device dari Flexibel AC Transmission System (FACTS) yang terdiri dari peralatan elektronika daya yang dapat mengatur aliran daya dan meningkat stabilitas transient sistem daya 


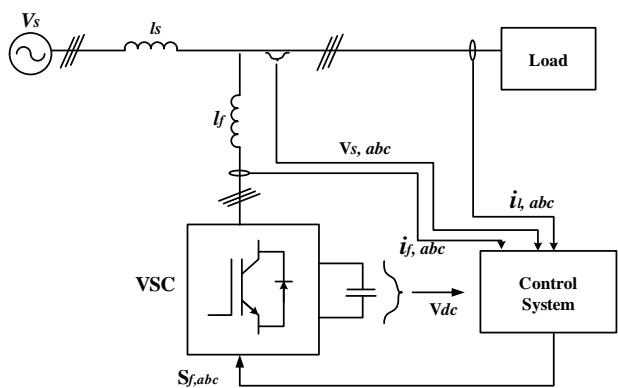

Gambar2: Struktur dari Statcom[5].

STATCOM terdiri dari beberapa bagian yaitu Voltage Source Converter (VSC), kapsitor DC, dan sistem kontrol. VSC ialah peralatan konverter elektronika daya yang berguna untuk mengkonversi tegangan masukan DC menjadi tegangan keluaran AC. Kapasitor DC berguna sebagai sumber tegangan untuk sistem kontrol STATCOM dan sebagai penyimpan energi (pada saat menyerap daya reaktif) dan sumber daya (pada saat menyuplai daya reaktif).

\section{H. Konverter 6 Pulsa}

Rangkaian Konverter 6 pulsa menggunakan enam buah diode dengan urutan konduksi untuk masing-masing diode yaitu $2 \pi / 3$.

Gambar3: Rangkaian Konverter 6 Pulsa[5].

\section{Voltage Source Converter (VSC)}

Voltage Source Converter (VSC) adalah bangunan utama dari STATCOM dan peralatan FACTS lainnya. VSC adalah komponen elektronika daya yang dapat diatur proses penyaklarannya sehingga tujuan yang diinginkan. Tujuan utama VSC yaitu membangkitkan tegangan sinusoidal AC dari tegangan DC, oleh karena itu VSC disebut konverter DC$\mathrm{AC}$ atau inverter.

\section{Metode Analisi Data Dan Simulasi Sistem}

Sumber data akan diperoleh dari Penyaluran dan Pusat Pengatur Beban (P3B) Bali. Area Pengatur Distribusi (APB) Bali bertempat di Jl. Raya Abianbase, Mengwi, Kabupaten Badung, Bali (80351).data yang dimaksud antara lain:

- Data single line sistem $150 \mathrm{kV}$ Bali

- Data Pembangkit (kV, MW, MVAR)

- Data Transformator (kV,MVA)

Made Dika Nugraha: Mereduksi Filter Aktif Pada... .
- Data saluran transmisi $150 \mathrm{kV}$ Bali (panjang R,X,Y)

- Data Bus ( kV \%)

- Data beban sistem $150 \mathrm{kV}$ Bali

Penelitian ini dimulai dengan survey data yang mendukung untuk disimulasikan dan dimodelkan pada Software PSCAD/EMTDC V 4.5 Power Simulation yang dapat mengetahui distorsi harmonisa tegangan dan arus yang masuk ke dalam sistem.

Simulasi dimulai dengan membuat diagram satu garis sistem transmisi $150 \mathrm{kV}$ Bali, masukkan data-data dari pembangkit, transformator, transmisi dan beban yang diperlukan, menjalankan

simulasi untuk keluaran aliran daya (load flow) dapat diketahui setelah program dapat dijalankan, ,untuk melihat keluaran aliran daya dari hasil simulasi di semua bus menurut standar SPLN No. 1:1995 Pasal 4 tentang ketentuan variasi tegangan pelayanan dimana drop tegangan yang diijinkan hanya sebesar $0.95 \mathrm{p} . u$ sampai $1.05 \mathrm{p} . \mathrm{u}$ dari tegangan nominal, setelah itu gunakan simulasi pada software PSCAD untuk pemasangan STATCOM.

Menambahkan nilai MVAR kepada bus-bus yang mengalami under voltage secara otomatis,kemudian tentukan lokasi penempatan STATCOM pada bus-bus, tes nilai total harmonic distortion (THDi $\geq 15 \%$ dan $T H D v \geq 5$ )

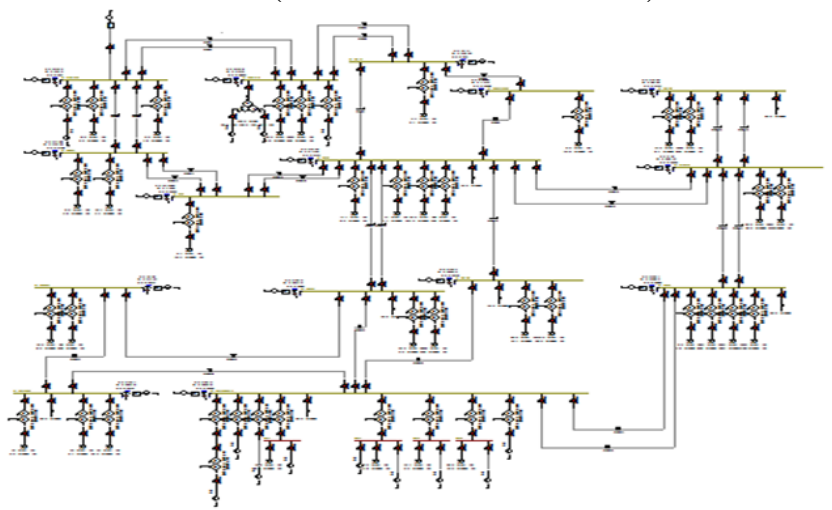

Gambar4: Simulasi Sistem Transmisi 150 kV Pada Software PSCAD.

Simulasi yang dilakukan pada PSCAD memasukan parameter-parameter sebagai berikut:

- Base Voltage (L-L,RMS) : $150.0 \mathrm{kV}$

- Base MVA : 327.617 [MVA]

- Terminal Voltage $\quad: 1.0[\mathrm{pu}]$

- Source Name :BWI-GLMANUK

- Source Impedance Type $\quad$ : R-R/L

- Graphics Display : : Single Line View

- 3 Phase Transformer : 10 [MVA]

- Base operation Frequency : :50 [Hz]

- Winding \#1 Type : Delta

- Winding \#2 Type : $Y$

- Winding 1 Line to Line Voltage (RMS)

$: 150.0[\mathrm{kV}]$

- Winding 2 Line to Line

Voltage (RMS) : $20.0[\mathrm{kV}]$

p-ISSN:1693 - 2951; e-ISSN: 2503-2372 


\section{A. Metode Aliran Daya (Loadflow)}

Secara matematis persamaan aliran daya dapat dituliskan sebagai berikut :

$$
\left[\begin{array}{c}
\Delta P \\
\Delta Q
\end{array}\right]=\left[\begin{array}{ll}
J_{1} & J_{2} \\
J_{3} & J_{4}
\end{array}\right]\left[\begin{array}{c}
\Delta \delta \\
\Delta|V|
\end{array}\right]
$$

Dimana: $\quad \Delta P$ adalah Nilai daya aktif (MW), $\Delta Q$ adalah Nilai daya reaktif (Mvar)

\section{B. Metode Optimasi Penempatan Kapasitor}

Tujuan dari penempatan kapasitor yang optimal dapat dipresentasikan secara matematis yaitu sebagai berikut :

$$
\begin{aligned}
& \text { Subject to: } \\
& \min =\mathrm{P}_{\text {Loss }}+\sum_{\mathrm{j}=1}^{\mathrm{J}} Q_{\mathrm{j}}^{\mathrm{c}}
\end{aligned}
$$

Dimana $P_{\text {Loss }}=$ Total rugi-rugi daya, $J=$ Jumlah Bus $Q_{j}^{c}=$ Penempatan kapasitas kapasitor pada bus $\mathrm{j}$

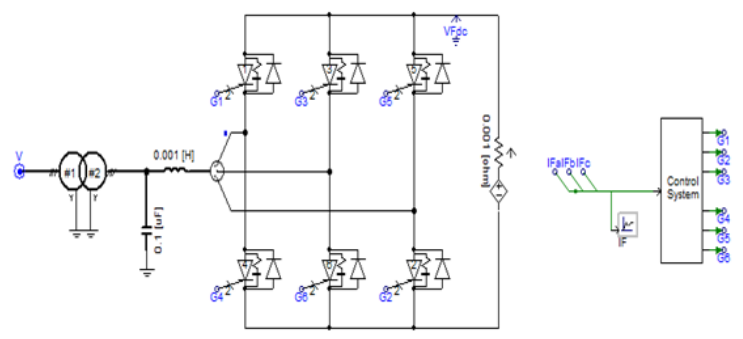

Gambar5: Simulasi 6 Pulse Statcom Pada Software PSCAD

\section{Metode Daya Aktif dan Daya Reaktif 6 Pulse Statcom}

$P=\frac{V_{s} V_{C} \sin \delta}{X_{L}}$

$\mathrm{Q}=\frac{\mathrm{V}_{\mathrm{S}}\left(\mathrm{V}_{\mathrm{S}}-\mathrm{V}_{\mathrm{C}} \sin \delta\right)}{\mathrm{X}_{\mathrm{L}}}$

$S=3 \frac{\mathrm{V}_{\mathrm{s}} \mathrm{V}_{\mathrm{C}}}{\mathrm{x}_{\mathrm{L}}} \sin \delta-\mathrm{j} 3\left[\frac{\mathrm{V}_{\mathrm{s}} \mathrm{V}_{\mathrm{C}}}{\mathrm{x}_{\mathrm{L}}} \cos \delta-\frac{\mathrm{V}_{\mathrm{s} 2}}{\mathrm{x}_{\mathrm{L}}}\right]=P-j(5)$

Dimana: $\mathrm{S}=$ Daya Kompleks (VA), $\mathrm{V}_{\mathrm{c}}=$ Tegangan Terminal Statcom, $\mathrm{V}_{\mathrm{s}}=$ Tegangan Sumber/Sistem, $\mathrm{P}=$ Daya Aktif, $\mathrm{X}_{\mathrm{L}}=$ Reaktansi (kabel) $=\omega L, \mathrm{Q}=$ Daya Reaktif (Var), $\alpha=$ Beda Fasa antara Vs dan Vc

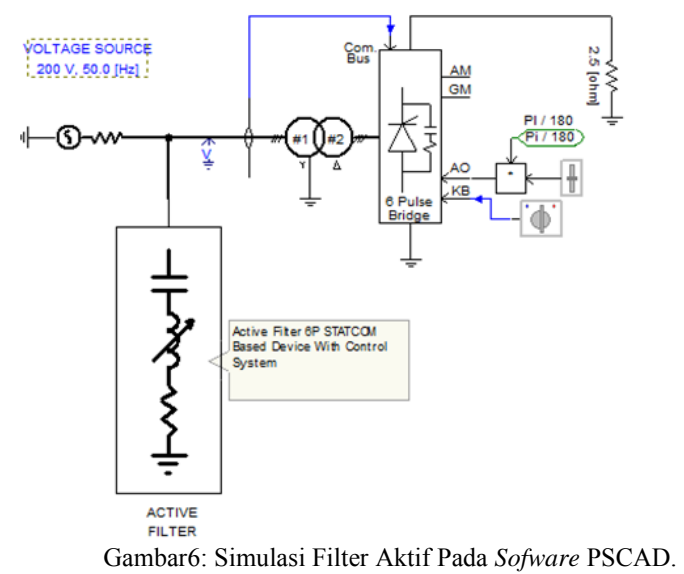

IV. HASIL SIMULASI DAN ANALISA DROP VOLTAGE TABELII

Perbandingan Level Tegangan Dalam Kondisi Awal ( Base Case), REAL KAPASITOR DAN PENEMPATAN STATCOM

\begin{tabular}{|c|c|c|c|c|}
\hline \multirow{2}{*}{ No } & \multirow{2}{*}{ Bus ID } & \multicolumn{3}{|c|}{ Tegangan (Pu) } \\
\cline { 3 - 5 } & $\begin{array}{c}\text { Base } \\
\text { Case }\end{array}$ & Kapasitor & STATCOM \\
\hline 1 & GI Gilimanuk & 0,9341 & 0,951 & 0,951 \\
\hline 2 & GI Pemaron & 0,9235 & 0.9405 & 0,9654 \\
\hline 3 & GI Baturiti & 0,9576 & 0,987 & 1,026 \\
\hline 4 & GI Pegyagan & 0.9504 & 0.9804 & 1,001 \\
\hline 5 & GI Ampra & 0,9488 & 0,9791 & 0,9991 \\
\hline 6 & GI Negara & 0,9486 & 0,9784 & 0,9978 \\
\hline 7 & GI Asari & 0,9692 & 0,9903 & 1,029 \\
\hline 8 & GI Kapal & 0,9468 & 0,9781 & 0,9981 \\
\hline 9 & GI Gianyar & 0,951 & 0,9803 & 1,001 \\
\hline 10 & GI Bandara & 0,9511 & 0,9812 & 0,9997 \\
\hline 11 & GI Pklod & 0,9336 & 0,9642 & 0,9875 \\
\hline 12 & GI Pbian & 0,9365 & 0,9674 & 0,9947 \\
\hline 13 & GI Sanur & 0,923 & 0,9549 & 0,9743 \\
\hline 14 & GI Nusa Dua & 0,9338 & 0,9673 & 0,9868 \\
\hline 15 & GI Psanggran & 0,9159 & 0,9656 & 0,9855 \\
\hline
\end{tabular}

Dari hasil analisis, dapat diketahui bahwa setelah penempatan STATCOM dapat meningkatkan profil tegangan hingga berada pada kondisi marginal yang sesuai standar SPLN yaitu padapada GI Gilimanuk dari 0,9341 p.u. menjadi 0,951 p.u, GI Pemaron dari 0,9235 p.u menjadi 0,9654 p.u, GI Ampra dari 0,9488 p.u menjadi 0,9991 p.u, GI Negara dari 0,9486 p.u menjadi 0,9978 p.u, GI Kapal dari 0,9468 p.u menjadi 0,9981 p.u, GI Pklod dari 0,9336p.u menjadi 0,9875p.u, GI Pbian dari 0.9365p.u menjadi 0.9947p.u, GI Sanur dari 0,923p.u menjadi 0.9743 p.u, GI Nusa Dua dari 0,9338 p.u menjadi 0,9868 p.u, dan GI Pesanggaran dari 0,9159p.u menjadi 0,9855 p.u. Serta dapat mengurangi rugi-rugi daya pada saluran transmisi dari 42,820 MW dan 80,232 MVar menjadi 32,514 MW dan 72,204 MVar. 


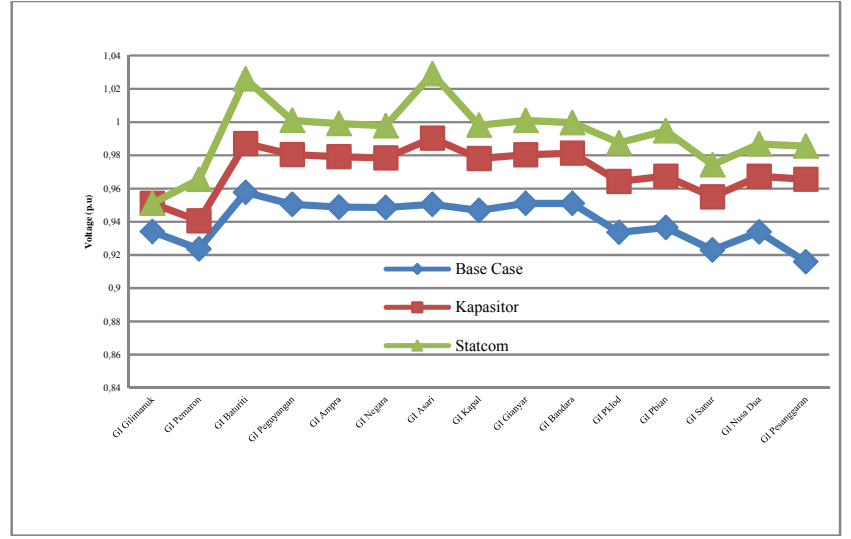

Gambar7: Perbandingan Level Tegangan Dalam Kondisi Awal, Real Kapasitor PLN dan Pemasangan 6 Pulse Statcom.

\section{HASIL SimUlasi DAN ANALISA THD}

A. Hasil Simulasi Harmonic Analysis Tanpa Filter Aktif pada 6 Pulse Statcom
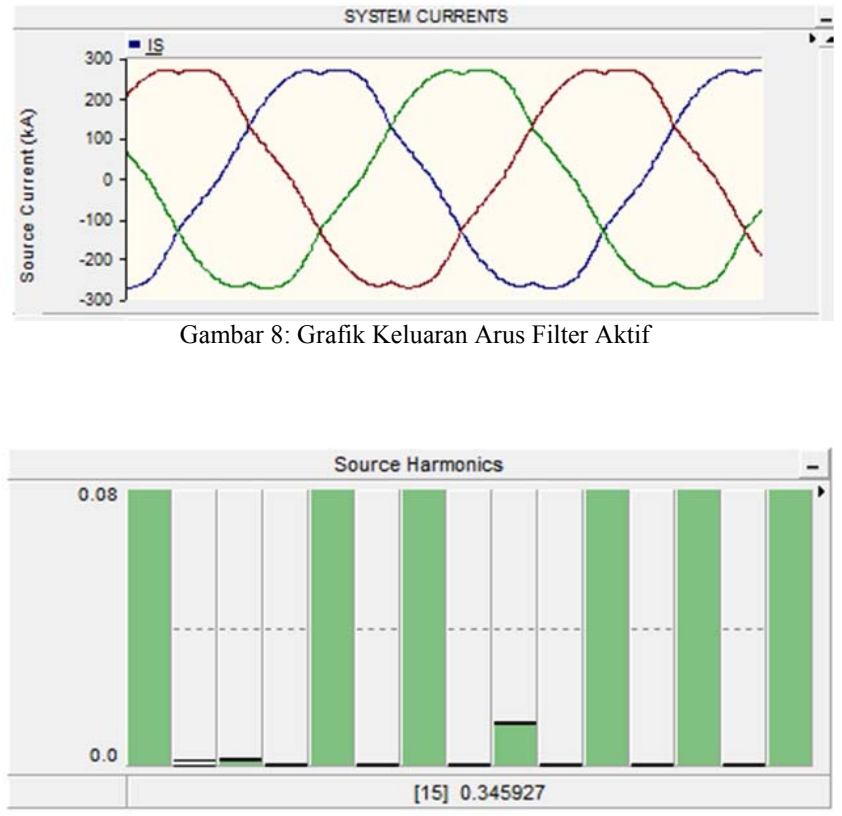

Gambar 9: Spektrum Arus Harmonisa Tanpa Filter Aktif

Pada spektrum harmonisa yang mempunyai orde dominan yang sama yaittu $5^{\text {th }}, 7^{\text {th }}, 11^{\text {th }}, 13^{\text {th }}$,dan $15^{\text {th }}$

B. Hasil Simulasi Harmonic Analysis Terpasang Filter Aktif pada 6 Pulse Statcom

Made Dika Nugraha: Mereduksi Filter Aktif Pada... .
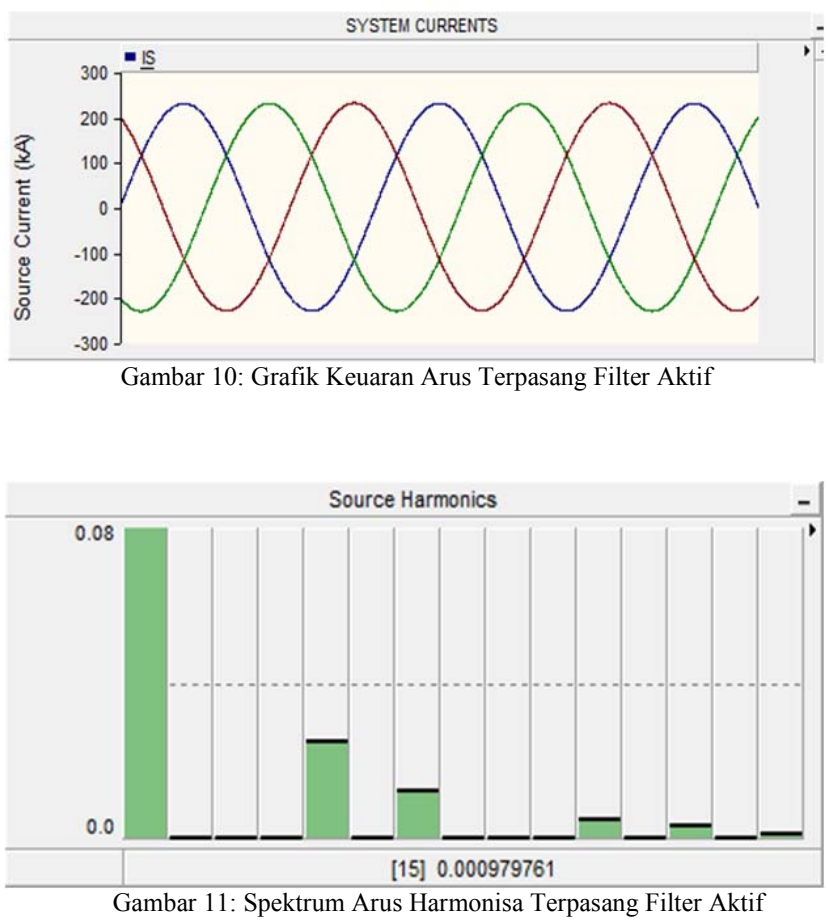

C. Hasil Perbandingan Tanpa dan Terpasang Filter Aktif

TABELIII

PERForma Sistem ARUS TANPA DAN TERPASANG FILTER AKTIF

\begin{tabular}{|c|c|c|c|}
\hline \multicolumn{2}{|c|}{ Konfigurasi Sistem } & $\begin{array}{c}\text { Tanpa } \\
\text { Filter Aktif }\end{array}$ & $\begin{array}{c}\text { Terpasang } \\
\text { Filter Aktif }\end{array}$ \\
\hline \multirow{4}{*}{$\begin{array}{c}\text { Harmonisa } \\
\text { Arus }\end{array}$} & $3^{\text {th }}$ & 0,0014 & 0,000230 \\
\cline { 2 - 4 } & $\mathbf{5}^{\text {th }}$ & 9,4736 & 0,0249 \\
\cline { 2 - 4 } & ${\mathbf{7}^{\text {th }}}^{\text {th }}$ & 3,4970 & 0,0117 \\
\cline { 2 - 4 } & ${\mathbf{9}^{\text {th }}}^{\mathbf{t i}^{\text {th }}}$ & 0,0120 & 0,000873 \\
\cline { 2 - 4 } & $\mathbf{1 1}^{\text {th }}$ & 0,9559 & 0,00486 \\
\cline { 2 - 4 } & $\mathbf{1 3}^{\text {th }}$ & 0,8188 & 0,00339 \\
\cline { 2 - 4 } & $\mathbf{1 5}^{\text {th }}$ & 0,3450 & 0,000979 \\
\hline
\end{tabular}

\section{KESIMPULAN}

Kondisi harmonisa arus pada jaringan transmisi Bali sebelum dan sesudah simulasi pemasangan filter aktif pada 6 pulse STATCOM yaitu orde $3^{\text {th }}$ mengalami distorsi gelombang harmonisa dari 0,0014 menjadi 0,000230 , orde $5^{\text {th }}$ dari 9,4736 menjadi 0,0249 , orde $7^{\text {th }}$ dari 3,4970 menjadi 0,0117 , orde $9^{\text {th }}$ dari 0,0120 menjadi 0,000873 , orde $11^{\text {th }}$ dari 0,9559 menjadi 0,00486 , orde $13^{\text {th }}$ dari 0,8188 menjadi 0,00339 , orde $15^{\text {th }}$ dari 0,3450 menjadi 0,000979 . 
Simulasi pemasangan dan pemodelan filter aktif diletakkan pada bus inti pada sistem transmisi $150 \mathrm{kV}$ Bali dan dihubungkan pada sisi sekunder transformator baru (STATCOM) serta diatur oleh VSC (Voltage Source Converter), dan Jika tegangan rendah (under voltage) maka STATCOM membangkitkan daya reaktif dari sistem (kapasitif) sedangkan jika tegangan tinggi (over voltage) maka menyerap daya reaktif (lagging). Filter aktif digunakan untuk mendistorsi gelombang harmonisa yang dihasilkan oleh beban non linier pada pengunnaan converter pada sistem injeksi MVAR STATCOM

\section{REFERENSI}

[1] K. K. Sen and M. L. Sen. 2009 , Introduction to FACTS controllers: theory, modeling, and applications. John Wiley \& Sons, , vol. 54.

[2] A. Edris. 2000, "Facts technology development: an update," IEEE Power engineering review, vol. 20.

[3] El-Moursi and A.M. Sharaf. 2005, "Novel controllers for the 48-pulse vsc STATCOM and ssscfor voltage regulation and reactive power compensation," IEEE Transactions on Powersystems, vol. 20.

[4] N. G. Hingorani and L. Gyugyi. 2000, Understanding FACTS: concepts and technology of flexible AC transmission systems. WileyIEEE press.

[5] B. Singh, R. Saha, A. Chandra, and K. Al-Haddad. 2009, "Static synchronous compensators (STATCOM): a review," IET Power Electronics, vol. 2.

[6] C. Schauder, M. Gernhardt, E. Stacey, T. Lemak, L. Gyugyi, T. Cease, and A. Edris. 1997, "Operation of 100 Mvartvastatcon," IEEE Transactions on Power Delivery, vol. 12
[7] I. Daut , H.S Syafuddin, dkk (2006) the effects of harmonic Components On Tranformer Losses Of SinunusoidalSource Supplying. Non-linear Loads, Malasysia : Science Publication

[8] Wayan Agus Adi Widiastra, I Wayan Rinas, I Wayan Sukerayasa. 2016, Analisis Pengaruh Total Harmonic Distortion Terhadap Losses dan Efisiensi Transformator RSUD Kabupaten Klungkung. Unud, Bali.

[9] Salam Z,dkk. (2006). Harmonics Mitigation Using Active Power Filter: A Technological Review. Department of Energy Conversion, Faculty of Electrical Engineering, University Teknologi Malaysia, ELEKTRIKA, 8(2),

[10] I Wayan Rinas (2011) "Analisi Perbandingan Penggunaan filter pasif dan filter aktif untuk menanggulangi THD pada sitem kelistrikan di ruang poskom jurusan teknik elektro fakulitas teknik universita udayana ".Unud, Bali.

[11] H. Akagi, Watanabe, E.H. dan Aredes. M, (2007) "Instantaneous Power Theory And Applications to Power Conditioning"

[12] Yusmantoro. Analisis Peningkatan Stabilitas Tegangan dengan Menggunakan Statcom Aplikasi PT. PLN (persero) UPB Sumbagut. Universitas Sumatera Utara,Medan

[13] Yahya Chusna Arif, Suryono, Mufakkirul Farih Pengurangan Harmonisa Pada Beban Konverter 6 Pulsa Dengan Filter Aktif (Injeksi Ripple Dc)Politeknik Elektronika Negeri Surabaya, Surabaya

[14] PT PLN (Persero) Area Pengatur Beban (APB) Bali. 2014. "Logsheet APB Bali'. Kapal Mengwi Badung Bali

[15] Kundur, Prabha. 1994. "Power System Stability and Control". Mc Graw-Hill Inc.

[16] Yamayee, Z.A. and Bala, J.L. Jr. Electromechanical Energy Devices and Power Systems, John Wiley and Sons, Inc., New York, 1994 